\title{
A POLIITICA E AS BASES DO DIREITO EDUCACIONAL
}

\author{
Evaldo VieirA*
}

\begin{abstract}
RESUMO: Este ensaio alude à relação entre sociedade, Estado e direito, tendo como elemento mediador a educação. Inicialmente, faz-se a exposição dos momentos distintos e marcantes da política social no século XX no Brasil: o primeiro período: a política social como controle da política (1930-1954); o segundo período: a política social como política de controle (1964-1988); o terceiro período: a política social sem direitos sociais (depois de 1988). Em seguida, passam-se por exame as idéias de sociedade civil; de cidadania; de direitos civis, políticos e sociais; caracterizando o chamado estado de direito democrático e indicando alguns elementos básicos da democracia. A Constituição Federal de 1988 consagra o estado de direito democrático e explicita a política educacional a ser implementada no Brasil. Tal política educacional é ampla-mente comentada, levando em conta os inúmeros artigos do texto constitucional e seus vínculos com tratados internacionais, anteriores, contemporâneos e posteriores a ela, no campo educacional. Além disso, a Constituição Federal reforça a tradição jurídica da educação nos textos constitucionais brasileiros, dando a ela a presunção de constitucionalidade. Na verdade, a Constituição de 1988 estabelece o regime jurídico da educação, por meio de diferentes artigos espalhados ao longo dela, convertendo-a em direito público subjetivo, o que é fundamental, porque os habitantes do Brasil têm direito de requerer ao Estado a prestação educacional, sob pena de ser responsabilizada a autoridade competente para oferecê-la. Há no ensaio a demonstração de que o Direito Educacional não se limita à simples exposição da legislação do ensino, pois a educação é um bem jurídico, individual e coletivo, embora as determinaçôes constitucionais nem sempre sejam cumpridas.
\end{abstract}

Palavras-chave: Política Social e Cidadania; Sociedade, Estado e Direito; Direito e Educação; Cidadania e Educação.

\footnotetext{
* Advogado, sociólogo, especialista em Direito e Doutor em Ciência Política na Universidade de São Paulo (USP); foi professor titular na USP, na Universidade Estadual de Campinas (Unicamp) e na Pontifícia Universidade Católica de São Paulo (PUC/SP). E-mail: evaldovieira@uol.com.br
} 
A política social percorre dois momentos políticos distintos e marcantes do século XX no Brasil: escrevendo sobre tal assunto anos atrás (1995, p. 229-233), denomino o primeiro período de controle da política, correspondendo à ditadura de Getúlio Vargas e ao populismo nacionalista, com influência para além de sua morte em 1954; e o segundo período, de política do controle, cobrindo a época da instalação da ditadura militar em 1964 até a conclusão dos trabalhos da Constituinte de 1988.

Nesses dois períodos, a política social brasileira compõe-se e recompõe-se, conservando em sua execução o caráter fragmentário, setorial e emergencial, sempre sustentada pela imperiosa necessidade de dar legitimidade aos governos, que buscam bases sociais para manter-se e aceitam seletivamente as reivindicações e até as pressões da sociedade.

A política social acha-se no terceiro período de existência no Brasil, depois de 1988, que chamo de política social sem direitos sociais.

Em nenhum momento a política social encontra tamanho acolhimento em Constituição brasileira, como acontece na de 1988 (artigos $6^{\circ}$ a 11): nos campos da Educação (pré-escolar, fundamental, nacional, ambiental etc.), da Saúde, da Assistência, da Previdência Social, do Trabalho, do Lazer, da Maternidade, da Infância, da Segurança, definindo especificamente direitos dos trabalhadores urbanos e rurais, da associação profissional ou sindical, de greve, da participação de trabalhadores e empregadores em colegiados dos órgãos públicos, da atuação de representante dos trabalhadores no entendimento direto com empregadores. O capítulo II, do Título II (Dos Direitos e Garantias Fundamentais), alude aos direitos sociais, pertencentes à Constituição de 1988.

De outra parte, poucos desses direitos estão sendo praticados ou ao menos regulamentados, quando exigem regulamentação. Porém, o mais grave é que em nenhum momento histórico da República brasileira (para só ficar nela, pois o restante consiste no Império escravista), os direitos sociais sofrem tão clara e sinceramente ataques da classe dirigente do Estado e dos donos da vida em geral, como depois de 1995.

Esses ataques aos direitos sociais, em nome de algo que se pode intitular de "neoliberalismo tardio" ou em nome da "modernização", alimentam-se no campo da política social, de forma geral, de falsas polêmicas. 
Geralmente, as análises relacionadas com a política social se debatem na falsa contraposição entre neoliberalismo e social-democracia. Ou, o mais sério, elas contrapóem o que chamam de política social neoliberal à política social de cunho social-democrata. Fazem uma tipologia dos Estados, fixando a oposição entre Estado de bem-estar liberal e Estado de bem-estar social-democrata, para em seguida, por vezes, admitir o surgimento de nova fase da acumulação capitalista (Laurell, 1995, p. 151-178).

Tais análises maniqueístas, que confrontam o Estado de bem-estar liberal com o Estado do bem-estar social-democrata, ou então a política social neoliberal com a política social de cunho social-democrata, mostram o limite das possibilidades nelas contidas, reduzindo o futuro imediato da história à social-democracia.

Nessas análises maniqueístas nada sucederá no futuro histórico, no novo século e no novo milênio, além da social-democracia.

Curiosamente, essas análises dão o nome de política social neoliberal àquela política que nega os direitos sociais, que garante o mínimo de sobrevivência aos indigentes, que exige contrapartida para o gozo dos benefícios, que vincula diretamente o nível de vida ao mercado, transformando-o em mercadoria.

Em geral, as políticas sociais envolvem direitos sociais, projetos, diretrizes, orçamentos, executores, resultados, impactos etc. Evidentemente, as políticas sociais devem sempre passar por avaliação, em qualquer lugar e época, constituindo exigência obrigatória quando custeadas com recursos pertencentes às sociedades. Porém, com a falta desses recursos fornecidos pelas sociedades, irrompem a cognominada "crise fiscal do Estado" e a febre avaliatória, pululando então avaliadores.

No Brasil, desde o tempo da elaboração da Constituição de 1988, a febre avaliatória ganha dimensão de epidemia e os avaliadores metamorfoseiam-se em festejados demiurgos, com a justificativa de preservar o bem e o patrimônio públicos, como se antes desta Constituição tal imperativo não existisse, nem se colocasse como irrevogável.

Os direitos sociais, os projetos, os executores, os processos, a eficiência, a eficácia, os resultados e os impactos das políticas sociais são em geral vistos e examinados pelos avaliadores como elementos de igual valor. O insidioso raciocínio localiza-se exatamente neste ilusório relativismo dos elementos das políticas sociais, apregoado pelos avaliadores. Em verdade, tais elementos dispōem de valores desiguais: por exemplo, não se suprimem a vida e a liberdade por onerarem o orçamento 
ou inexistirem fontes de financiamento para elas, embora abundem os defensores desta posição irracionalista.

$\mathrm{Na}$ avaliação dos elementos das políticas sociais, o mínimo esperado é que os direitos sociais gozem da posição de respeito e de superioridade, por inclusive participarem da Constituição de 1988, uma das mais livremente votadas no Brasil, integrando o Título II, relativo aos Direitos e Garantias Fundamentais. Caso contrário, sobra apenas como fúnebre consolação curvar-se ao irracionalismo da meritocracia e ao seu relativismo nas políticas sociais.

No caso brasileiro, depois da extinção dos direitos sociais, quem sabe se não chegará a vez de fraquejarem o Estado de direito e o regime democrático-liberal? A tradição histórica do Brasil revela constante intervenção estatal no âmbito da política social, alicerçada ao longo do século $\mathrm{XX}$ em direitos sociais variados e gradativamente conquistados.

A política econômica brasileira é exemplar neste aspecto: mesmo em ocasiões de negação explícita de sua presença na economia, o Estado funciona como salvaguarda e como propulsor dos detentores de capital.

Agora, nesta etapa de desemprego em massa e de privaçôes ilimitadas, a intervenção estatal é imprescindível para concretizar os direitos sociais contidos na Constituição de 1988, visando construir e afiançar a segurança social no Brasil.

\section{II}

A idéia de sociedade civil está ligada ao pensamento liberal, que ganha projeção no século XVIII e representa a sociedade dos cidadãos. $\mathrm{O}$ termo civil aqui significa que a sociedade forma-se de cidadão, entendido como aquele que tem direitos e deveres. Nessa época em que a palavra "cidadão" sobressai, ela se contrapõe à palavra "súdito", que quer dizer aquele que obedece. A temática relacionada com a sociedade civil liga-se ao conceito de cidadão.

Civil, que indica cidadão, ganha complexidade com o passar do tempo. Os direitos mais restritos, existentes dentro do conceito de cidadão, transformam-se em muitos direitos de cidadania, tornam-se direitos civis (as garantias individuais), direitos políticos (por exemplo: de reunião, de expressão de pensamento, de voto, de organização de partido) e depois, no século XX, direitos sociais. Os direitos sociais são recentes, posteriores à Primeira Guerra Mundial, ou seja, posteriores a 1919. Portanto, a idéia de sociedade civil sugere a idéia de cidadania de uma sociedade 
criada dentro do capitalismo, de uma sociedade vista como um conjunto de pessoas iguais em seus direitos.

Nesta sociedade, cidadania representa igualdade jurídica. Há quem elabore outros conceitos de cidadania, considerando-a igualdade social, igualdade real. De fato, a cidadania fundamenta-se no princípio de que as pessoas são iguais perante a lei e unicamente perante a lei, porque a cidadania consiste em instrumento criado pelo capitalismo para compensar a desigualdade social, isto é, a situação em que alguns acumulam riquezas, acumulam propriedades, enquanto outros não. Então, não existe cidadania sem garantias de direitos, não existe cidadania sem igualdade jurídica.

Alguns defendem o princípio de que ocorre uma cidadania sem o Estado. Defendem que é possível desenvolver uma cidadania em que os próprios grupos estabelecem-na.

Por outro lado, é certo que os direitos de cidadania historicamente nascem na sociedade, que nascem entre os trabalhadores, entre os miseráveis, entre os despossuídos. Eles reivindicam seus direitos e conseguem ao longo de mais de dois séculos para cá alcançar alguns deles.

Os direitos gerados dentro da cidadania só se transformam em leis, em imperatividade jurídica, quando são conquistados e impostos. Os direitos sociais, por exemplo, florescem com uma guerra mundial, a Primeira Guerra Mundial, e depois a Segunda Guerra Mundial permite o aparecimento do chamado "Estado do Bem-Estar Social", em certos países industrializados.

Os principais direitos fundamentais compóem o chamado Estado de direito democrático. O Estado de direito aparece no liberalismo, todavia o Estado de direito democrático impõe algo mais: o princípio da soberania popular. Este princípio diz que o governo e o Estado necessitam de legitimidade vinda do povo.

O Estado de direito democrático requer soberania popular, em geral enganosamente entendida como expressão do voto. Alega-se o seguinte: o Estado é democrático porque há o voto. Ingenuidade flagrante, porque o Estado pode ser antidemocrático e ter o voto. Napoleão I estabeleceu uma tirania na França, a partir do final do século XVIII, realizando plebiscito e ganhando com enorme maioria de votos. $\mathrm{O}$ consenso eleitoral representa algo fugidio e a sociedade não pode ficar nisto, não pode fundar nela a legitimação democrática do Estado, é imprescindível o controle social dele. 
O Estado de direito democrático exige o voto universal, o voto para todas as pessoas, mas o voto não passa de um de seus componentes para garantir a soberania popular. Outro componente básico é o controle social da administração pública.

Determinadas sociedades permitem maior controle social da administração pública do que outras. Como forma de ação democrática, o controle social da administração pública representa um dos elementos mais importantes da democracia.

A democracia não constitui um estágio, ela constitui um processo. O processo pelo qual a soberania popular vai controlando e aumentando os direitos e os deveres é um processo prolongado, implicando avanço muito grande dentro da sociedade. Quanto mais coletiva é a decisão, mais democrática ela é. Qualquer conceito de democracia, aliás há vários deles, importa em grau crescente de coletivização das decisōes. Quanto mais o interesse geral envolve um conjunto de decisões, mais democráticas elas são. O Estado e o governo sofrem processo de democratização ou de antidemocratização. Quanto menos interesses coletivos, quanto menos coletivização existe nas decisões e, portanto, quanto mais particularização existe nas decisões, menos democrático ou nada democrático é o governo.

Se a sociedade é fortemente democrática, tende a construir governo democrático, mas sociedade dominantemente autoritária, discriminatória, violenta, não tende a sustentar esta espécie de governo. O Estado não cria a sociedade, mas acontece o contrário. Determinada sociedade expressa em determinado Estado e em determinado governo suas necessidades individuais e grupais, suas ansiedades, seus preconceitos, suas contradições e sua maldade, os quais estão presentes em várias circunstâncias passíveis de análise.

\section{III}

A Constituição da República Federativa do Brasil, de 5 de outubro de 1988, estabelece direitos civis, políticos e sociais. A realização desses direitos exige a mobilização da sociedade, porque dela nascem as necessidades e as angústias.

Com relação à política educacional, a Constituição Federal de 1988 concede amplos direitos, confirmando e ampliando o interesse social pela educação. Desde a Constituiçãao monárquica de 1824 , a primeira Constituição brasileira, a educação irrompe como o fundamento da política social, que só alcança maior abrangência durante o século XX. No 
final deste século, falou-se bastante a respeito da educação e de sua importância, porém muito se desarticulou a aplicação dos direitos educacionais.

Nina Beatriz Ranieri descreve a participação estatal na educação superior, da seguinte maneira:

O Estado brasileiro tem presença expressiva no campo da educação superior: planeja, define políticas e as executa; legisla; regulamenta; interpreta e aplica a legislação por meio dos Conselhos de Educação; financia e subvenciona o ensino, a pesquisa e a extensão de serviços; mantém universidades e demais instituições públicas de ensino superior; oferece diretamente ensino de graduação e pós-graduação; autoriza, reconhece, credencia, recredencia, supervisiona cursos e instituiçôes; determina suas desativações; avalia alunos, cursos e instituiçôes por todo o País; interfere na organização do ensino; estabelece diretrizes curriculares etc. Tudo se dá na esfera pública e na privada, e em relação a todos os sistemas de ensino. (2000, p. 23)

A atuação do Estado brasileiro não é diferente nos outros ramos de ensino, notadamente no fundamental e no médio. A Constituição determina a vida social, política e jurídica do Brasil, organizando o Estado. Ao ordenar a sociedade e o Estado, a Constituição também dispõe sobre a educação e sobre a forma de concretizá-la.

Assim, quando se buscam as bases do Direito Educacional, o ponto de partida deve estar na Constituição, naqueles princípios abrangentes, capazes de multiplicarem-se em muitos direitos, em muitas garantias e muitos deveres.

Neste caso, é necessário considerar o artigo $3^{\circ}$ da Constituição Federal de 1988:

Art. $3^{\circ}$ - Constituem objetivos fundamentais da República Federativa do Brasil: I - construir uma sociedade livre, justa e solidária; II - garantir o desenvolvimento nacional; III - erradicar a pobreza e a marginalização e reduzir as desigualdades sociais e regionais; IV - promover o bem de todos, sem preconceitos de origem, raça, sexo, cor, idade e quaisquer outras formas de discriminação.

Entrelaçando educação e desenvolvimento, Pinto Ferreira considera o seguinte:

A fórmula educação para o desenvolvimento é realmente proveitosa, entretanto difícil se torna a educação sem o desenvolvimento, já que a educação, sendo um privilégio de minorias privilegiadas e ricas, só floresce nas áreas de prosperidade, e não nas áreas de pobreza. (1995, p. 261) 
A presença da educação na Constituição Federal deve ser examinada necessariamente com base nesses objetivos expostos no artigo $3^{\circ}$, dos quais ela não pode estar de nenhum modo afastada.

Os princípios básicos, contidos no artigo $3^{\circ} \mathrm{da}$ Constituição, devem influir na teoria e na prática educacionais derivadas do Capítulo III, denominado "Da Educação, da Cultura e do Desporto", no Titulo VIII (Da Ordem Social), juntamente com outros preceitos distribuídos ao longo do texto constitucional.

Por outro lado, os direitos e garantias fundamentais, discriminados no Título II, da Constituição Federal de 1988, constituem os outros princípios básicos a serem obedecidos na teoria e na prática educacionais, contidas no Capítulo III, do Título VIII. Estes direitos do homem somente se realizam quando estão sustentados nas garantias constitucionais, não tendo, sem elas, qualquer validade prática.

Os principais direitos do homem são declarações e as garantias fundamentais representam os instrumentos necessários à efetivação deles. A ordem constitucional do Brasil protege a vida, a liberdade, a segurança e a propriedade de todos que estejam a ela subordinados. Portanto, nesta ordem constitucional se incluem os direitos educacionais especialmente do aluno, do professor, da escola e da família.

Por sinal, estes direitos e garantias fundamentais já constam da Declaração Universal de Direitos, aprovada pela Assembléia Geral das Naçôes Unidas então reunida em Paris, no dia 10 de dezembro de 1948, da qual o Brasil é signatário. Antes da Constituição Federal de 1988, o Brasil reconhece o que está escrito na "Proclamação" de 1948, a qual alude ao ensino e à educação:

A PRESENTE DECLARAÇÃO UNIVERSAL DE DIREITOS HUMANOS
como ideal comum pelo qual todos os povos e nações devem esforçar-se, a fim
de que tanto os indivíduos como as instituiçōes, inspirando-se constantemente
nela, promovam, mediante o ensino e a educação, o respeito a estes direitos e
liberdades, e assegurem, por medidas progressivas de caráter nacional e inter-
nacional, seu reconhecimento e aplicação universais e efetivos, tanto entre os
povos dos Estados Membros como entre os dos territórios colocados sob sua
jurisdição. (Maiúsculas do texto).

Ocupando-se particularmente da educação, a Declaração Universal de Direitos Humanos, da Organização das Naçōes Unidas (ONU), feita em 1948, prescreve: 
Artigo 26. 1. Toda pessoa tem direito à educação. A educação deve ser gratuita, ao menos na instrução elementar e fundamental. A instrução elementar será obrigatória. A instrução técnica e profissional haverá de ser generalizada; o acesso ao estudos superiores será igual para todos, em função dos méritos respectivos. 2. A educação terá por objeto o pleno desenvolvimento da personalidade humana e o fortalecimento do respeito aos direitos humanos e às liberdades fundamentais; favorecerá a compreensão, a tolerância e a amizade entre todas as naçōes e todos os grupos étnicos ou religiosos; e promoverá o desenvolvimento das atividades das Nações Unidas para a manutenção da paz. 3. Os pais terão direito preferencial para escolher o tipo de educação que se dará a seus filhos.

Em certo sentido, a comunidade internacional, na qual o Brasil se insere, por intermédio da Declaração Universal de Direitos Humanos da ONU, antecede e inspira a Constituição Federal de 1988, somandose às exigências da sociedade brasileira, também no campo educacional, além de outros.

Relativamente à educação, o Brasil submete-se a pactos internacionais, firmados por ele, como por exemplo só na década de 1990: a Conferência Internacional de Educação para Todos, Jomtien, Tailândia, 1990; a Declaração de Nova Delhi, Índia, 1993; a Conferência Internacional sobre População e Desenvolvimento, Cairo, Egito, 1994; a Cúpula Mundial de Desenvolvimento Social, Copenhague, Dinamarca, 1995; a $4^{a}$ Conferência sobre a Mulher, Beijing, China, 1995; a Afirmação de Aman, Jordânia, 1996; a 45 Conferência Internacional da Unesco, Genebra, Suíça, 1996 e a Declaração de Hamburgo, Alemanha, 1997.

Quanto à gratuidade na educação, destaque-se o Pacto Internacional sobre Direitos Econômicos, Sociais e Culturais, de 1992, que a assegura no artigo 13:

a) educação primária deverá ser obrigatória e acessível gratuitamente a todos; b) a educação secundária em suas diferentes formas, inclusive a educação secundária técnica e profissionalizante, deverá ser generalizada e tornar-se acessível a todos, por todos os meios apropriados e, principalmente, pela implementação progressiva do ensino gratuito; c) a educação de nível superior deverá igualmente tornar-se acessível a todos, com base na capacidade de cada um, por todos os meios apropriados e, principalmente, pela implementação progressiva do ensino gratuito. (Cf. Ranieri, 2000, p. 75 e 76). 
Como se notou antes, a educação se apresenta em todas as Constituições do Brasil, na imperial de 1824 e nas demais republicanas: de 1891, 1934, 1946, 1967 e de 1988. A Constituição da monarquia brasileira traz dois itens, de números 32 e 33, do artigo 179, que se referem à educação. $O$ primeiro item garante a gratuidade da educação primária e o segundo item faz menção à criação de colégios e de universidades.

A persistência da atividade educativa nas Constituições do Brasil pode dar a impressão de que pode ser verdadeira, ao menos quanto a ela, sua presunção da constitucionalidade. Carlos Maximiliano afirma: "Forte é a presunção da constitucionalidade de um ato ou de uma interpretação, quando datam de grande número de anos, sobretudo se foram contemporâneos da época em que a lei fundamental foi votada." (1981, p. 307)

Na Constituição Federal de 1988, a educação compóe os direitos sociais, junto com outros direitos. A Constituição Federal relaciona os direitos sociais em seu artigo $6^{\circ}$ e posteriormente particulariza-os no Título VIII (Da Ordem Social): "Art. $6^{\circ}$ - São direitos sociais a educação, a saúde, o trabalho, o lazer, a segurança, a previdência social, a proteção à maternidade e à infância, a assistência aos desamparados, na forma desta Constituição."

Os direitos individuais e os direitos sociais consistem num todo, a exigir um procedimento diferente do Estado, quanto a eles. São esclarecedoras as observações de Celso Ribeiro Bastos sobre a distinção de procedimento estatal, ante os direitos individuais ou os direitos sociais:

Ao lado dos direitos individuais, que têm por característica fundamental a imposição de um não fazer ou abster-se do Estado, as modernas Constituiçôes impõem aos Poderes Públicos a prestação de diversas atividades, visando o bem-estar e o pleno desenvolvimento da personalidade humana, sobretudo em momentos em que ela se mostra mais carente de recursos e tem menos possibilidade de conquistá-los pelo seu trabalho. (1998, p. 259)

Os direitos individuais implicam o não fazer do Estado, enquanto os direitos sociais impóem-lhe um fazer e uma maior positividade, como assevera José Afonso da Silva:

os direitos sociais, como compreensão dos direitos fundamentais do homem, são prestações positivas estatais, enunciadas em normas constitucionais, que 
possibilitam melhores condições de vida aos mais fracos, direitos que tendem a realizar a igualização de situaçôes sociais desiguais. (1992, p. 258)

As políticas sociais, apoiadas em direitos sociais, tornam obrigatórias e imediatas as medidas estatais para elevar a condição humana dos titulares desses direitos. Tais medidas vêm em resposta às necessidades sociais e transformam em realidade os direitos sociais, sobressaindo nas medidas os pobres e os miseráveis.

$\mathrm{Na}$ educação, as medidas originárias de direitos sociais e de políticas sociais significam ônus do Estado, de acordo com a Constituição Federal de 1988.

\section{V}

Constitucionalmente, a educação brasileira deve ser direito de todos e obrigação do Estado; deve acontecer em escolas; deve seguir determinados princípios; deve ratificar a autonomia universitária; deve conservar a liberdade de ensino; e principalmente deve converter-se em direito público subjetivo, com a possibilidade de responsabilizar-se a autoridade competente.

Por sua grande importância, é preciso indicar aqui os artigos do regime jurídico da educação, na Constituição Federal de 1988:

Art. 205 - A educação, direito de todos e dever do Estado e da família, será promovida e incentivada com a colaboração da sociedade, visando ao pleno desenvolvimento da pessoa, seu preparo para o exercício da cidadania e sua qualificação para o trabalho.

Art. 206 - O ensino será ministrado com base nos seguintes princípios: I igualdade de condições para o acesso e permanência na escola; II - liberdade de aprender, ensinar, pesquisar e divulgar o pensamento, a arte e o saber; III pluralismo de idéias e de concepções pedagógicas, e coexistência de instituições públicas e privadas de ensino; IV - gratuidade do ensino público em estabelecimentos oficiais; $\mathrm{V}$ - valorização dos profissionais do ensino, garantidos, na forma da lei, planos de carreira para o magistério público, com piso salarial profissional e ingresso exclusivamente por concurso público de provas e títulos; VI - gestão democrática do ensino público, na forma da lei; VII - garantia de padrão de qualidade.

Art. 207 - As universidades gozam de autonomia didático-científica, administrativa e de gestão financeira e patrimonial, e obedecerão ao princípio de indissociabilidade entre ensino, pesquisa e extensão. Parágrafo 1- É facultado às universidades admitir professores, técnicos e cientistas estrangeiros, na forma 
da lei. Páragrafo $2^{\circ}$ - O disposto neste artigo aplica-se às instituiçōes de pesquisa científica e tecnológica.

Art. 208 - O dever do Estado com a educação será efetivado mediante a garantia de: I - ensino fundamental obrigatório e gratuito, assegurada, inclusive, sua oferta gratuita para todos os que a ele não tiveram acesso na idade própria; II - progressiva universalização do ensino médio gratuito; III - atendimento educacional especializado aos portadores de deficiência, preferencialmente na rede regular de ensino; IV - atendimento em creche e pré-escola às crianças de zero a seis anos de idade; $\mathrm{V}$ - acesso aos níveis mais elevados do ensino, da pesquisa e da criação artística, segundo a capacidade de cada um;

VI - oferta de ensino noturno regular, adequado às condiçóes do educando; VII - atendimento ao educando, no ensino fundamental, através de programas suplementares de material didático-escolar, transporte, alimentação e assistência à saúde. Parágrafo $1^{\circ}-\mathrm{O}$ acesso ao ensino obrigatório e gratuito é direito público subjetivo. Parágrafo $2^{\circ}$ - O não-oferecimento do ensino obrigatório pelo Poder Público, ou sua oferta irregular, importa responsabilidade da autoridade competente. Parágrafo $3^{\circ}$ - Compete ao Poder Público recensear os educandos no ensino fundamental, fazer-lhes a chamada e zelar, junto aos pais ou responsáveis, pela freqüência à escola.

Art. 209 - O ensino é livre à iniciativa privada, atendidas as seguintes condiçôes: I - cumprimento das normas gerais da educação nacional; II - autorização e avaliação de qualidade pelo Poder Público.

Art. 210 - Serão fixados conteúdos mínimos para o ensino fundamental, de maneira a assegurar formação básica comum e respeito aos valores culturais e artísticos, nacionais e regionais. Parágrafo $1^{\circ}$ - $\mathrm{O}$ ensino religioso, de matrícula facultativa, constituirá disciplina dos horários normais das escolas públicas de ensino fundamental. Parágrafo $2^{\circ}-\mathrm{O}$ ensino fundamental regular será ministrado em língua portuguesa, assegurada às comunidades indígenas também a utilização de suas línguas maternas e processos próprios de aprendizagem.

Art. 211 - A União, os Estados, o Distrito Federal e os Municípios organizarão em regime de colaboração seus sistemas de ensino. Parágrafo $1^{\circ}$ - A União organizará o sistema federal de ensino e o dos Territórios, financiará as instituições de ensino públicas federais e exercerá, em matéria educacional, função redistributiva e supletiva, de forma a garantir equalização de oportunidades educacionais e padrão mínimo de qualidade do ensino mediante assistência técnica e financeira aos Estados, ao Distrito Federal e aos Municípios. Parágrafo $2^{\circ}$ - Os Municípios atuarão prioritariamente no ensino fundamental e na educação infantil. Parágrafo $3^{\circ}$ - Os Estados e o Distrito Federal atuarão prioritariamente no ensino fundamental e médio. Parágrafo $4^{\circ}-\mathrm{Na}$ organização de seus sistemas de ensino, os Estados e os Municípios definirão formas de colaboração, de modo a assegurar a universalização do ensino obrigatório.

Art. 212 - A União aplicará, anualmente, nunca menos de dezoito, e os Estados, o Distrito Federal e os Municípios vinte e cinco por cento, no mínimo, da 
receita resultante de impostos, compreendida a proveniente de transferências, na manutenção e desenvolvimento do ensino. Parágrafo $1^{\circ}$ - A parcela da arrecadação de impostos transferida pela União aos Estados, ao Distrito Federal e aos Municípios, ou pelos Estados aos respectivos Municípios, não é considerada, para efeito do cálculo previsto neste artigo, receita do governo que a transferir. Parágrafo $2^{\circ}$ - Para efeito do cumprimento do disposto no "caput" deste artigo, serão considerados os sistemas de ensino federal, estadual e municipal e os recursos aplicados na forma do art. 213. Parágrafo $3^{\circ}$ - A distribuição dos recursos públicos assegurará prioridade ao atendimento das necessidades do ensino obrigatório, nos termos do plano nacional de educação. Parágrafo $4^{\circ}$ Os programas suplementares de alimentação e assistência à saúde previstos no art. 208, VII, serão financiados com recursos provenientes de contribuições sociais e outros recursos orçamentários. Parágrafo $5^{\circ}$ - $\mathrm{O}$ ensino fundamental público terá como fonte adicional de financiamento a contribuição social do salário-educação recolhida, pelas empresas, na forma da lei.

Art. 213 - Os recursos públicos serão destinados às escolas públicas, podendo ser dirigidos a escolas comunitárias, confessionais ou filantrópicas, definidas em lei, que: I - comprovem finalidade não-lucrativa e apliquem seus excedentes financeiros em educação; II - assegurem a destinação de seu patrimônio a outra escola comunitária, filantrópica ou confessional, ou ao Poder Público, no caso de encerramento de suas atividades. Parágrafo $1^{\circ}$ - Os recursos de que trata este artigo poderão ser destinados a bolsas de estudo para o ensino fundamental e médio, na forma da lei, para os que demonstrarem insuficiência de recursos, quando houver falta de vagas e cursos regulares da rede pública na localidade da residência do educando, ficando o Poder Público obrigado a investir prioritariamente na expansão de sua rede na localidade. Parágrafo $2^{\circ}$ - As atividades universitárias de pesquisa e extensão poderão receber apoio financeiro do Poder Público.

Art. 214 - A lei estabelecerá o plano nacional de educação, de duração plurianual, visando à articulação e ao desenvolvimento do ensino em seus diversos níveis e à integração das ações do Poder Público que conduzam à: I - erradicação do analfabetismo; II - universalização do atendimento escolar; III - melhoria da qualidade do ensino; IV - formação para o trabalho; $\mathrm{V}$ - promoção humanística, científica e tecnológica do País.

O regime jurídico da educação é formado ainda por outros artigos da Constituição Federal de 1988. Estes artigos acham-se dispersos no texto constitucional e, para maior brevidade, pode-se utilizar a concisa classificação feita por Edivaldo M. Boaventura, com atualizações (1995, p. 39 e 40):

A) Competências em educação: 1) Competência privativa da União: estabelecer diretrizes e bases da educação nacional: artigo 22, XXIV; 2) Competência da União, dos Estados, do Distrito Federal e dos Municípios: proporcionar meios 
de acesso à educação: artigo 23, V; 3) Competência da União, dos Estados e do Distrito Federal: legislar concorrentemente sobre educação: artigo 24, IX; 4) Competência comum da União, dos Estados, do Distrito Federal e dos Municípios: fixar e implantar política de educação para a segurança do trânsito: artigo 23, XII; 5) Competência legislativa e suplementar dos Estados no campo educacional: artigo 24, parágrafo $2^{\circ}$.

\section{B) Demais mençães da educação no interior da Constituição Federal de} 1988: 1) Educação como direito social: artigo 60, "caput"; 2) Educação ambiental: artigo 225, parágrafo $1^{\circ}$, VI; 3) Eliminação do analfabetismo e universalização do ensino fundamental nos dez primeiros anos da promulgação da Constituição: Ato das Disposições Constitucionais Transitórias (ADCT), artigo 60, "caput", combinado com o artigo 214 da Constituição; 4) Recebimento de recursos públicos pelas escolas comunitárias, confessionais, filantrópicas, fundações de ensino e pesquisa: Ato das Disposições Constitucionais Transitórias (ADCT), artigo 61, "caput"; 5) Colégio Pedro II, da cidade do Rio de Janeiro, continua no sistema federal de educação: artigo 242, parágrafo 2o; 6) Ensino da História do Brasil: artigo 242, parágrafo 1\%; 7 ) Assistência educacional gratuita ao ex-combatente, extensiva aos dependentes: Ato das Disposiçōes Constitucionais Transitórias (ADCT), artigo 53, IV; 8) Imunidade tributária às instituiçōes educacionais e de assistência social, sem fins lucrativos: artigo 150, VI, "c"; 9) Competência dos Municípios para manter programas de educação pré-escolar e de ensino fundamental: artigo 30, VI; 10) Creches e pré-escolas aos filhos e dependentes dos trabalhadores urbanos e rurais, desde o nascimento até seis anos de idade: artigo 7, XXV, combinado com o artigo 208, IV; 11) Criação por lei do Serviço Nacional de Aprendizagem Rural (SENAR),: Ato das Disposiçōes Constitucionais Transitórias (ADCT), artigo 62; 12) Garantia de acesso do trabalhador adolescente à escola: artigo 227, parágrafo $3^{\circ}$, III; 13) Exceção da gratuidade do ensino público, nas instituiçôes educacionais oficiais, criadas por lei estadual ou municipal e existentes na data da promulgação da Constituição: artigo 242, "caput"; 14) Intervenção do Estado em seus Municípios e da União nos Municípios localizados em Território Federal, por não aplicar o mínimo exigido da receita municipal no ensino: artigo 35, III; 15) A família, a sociedade e o Estado têm o dever de assegurar à criança e ao adolescente, com absoluta prioridade, o direito à educação: artigo 227, "caput"; 16) Salário mínimo capaz de atender às necessidades vitais básicas dos trabalhadores urbanos e rurais, e também às de sua família com moradia, alimentação, educação, saúde, lazer, vestuário, higiene, transporte e previdência social: artigo $7^{\circ}$, IV.

\section{VI}

A educação, como direito público subjetivo, cria a situação em que é preciso haver escolas para todos, seguindo o disposto no regime jurídico constitucional e dando maior realce ao Poder Judiciário neste setor. 
Os indivíduos têm o direito de requerer ao Estado a prestação educacional, porque o descumprimento deste dever traz como conseqüência a responsabilização da autoridade competente, segundo o artigo 208, parágrafos $1^{\circ}$ e $2^{\circ}$, da Constituição Federal de 1988.

No quadro das garantias constitucionais, o mandado de segurança mostra-se um instrumento jurídico de destaque no Direito Educacional, podendo ser empregado amplamente, mesmo como mandado de segurança coletivo, em favor da escola, da atividade educativa e da vida acadêmica, protegendo direito líquido e certo, demonstrado imediatamente, e não mera expectativa de direito.

A Constituição Federal de 1988 define o mandado de segurança, no artigo $5^{\circ}$, LXIX:

Art. $5^{\circ}$ - ...Todos são iguais perante a lei, sem distinção de qualquer natureza, garantindo-se aos brasileiros e aos estrangeiros residentes no País a inviolabilidade do direito à vida, à liberdade, à igualdade, à segurança e à propriedade, nos termos seguintes:

(..)

LXIX - conceder-se-á mandado de segurança para proteger direito líquido e certo, não amparado por "habeas corpus" ou "habeas data", quando o responsável pela ilegalidade ou abuso de poder for autoridade pública ou agente de pessoa jurídica no exercício de atribuiçōes do Poder Público.

No que diz respeito ao mandado de segurança coletivo, a Constituição Federal preceitua no artigo $5^{\circ}$, LXX:

Art. $5^{\circ}-(.$.

LXX - o mandado de segurança coletivo pode ser impetrado por: a) partido político com representação no Congresso Nacional; b) organização sindical, entidade de classe ou associação legalmente constituída e em funcionamento há pelo menos um ano, em defesa dos interesses de seus membros ou associados.

Como inovação, há na Constituição de 1988 o mandado de injunção, exposto em seu artigo $5^{\circ}$, LXXI:

Art. $5^{\circ}-(\ldots)$

LXXI - conceder-se-á mandado de injunção sempre que a falta de norma regulamentadora torne inviável o exercício dos direitos e liberdades constitucionais e das prerrogativas inerentes à nacionalidade, à soberania e à cidadania. 
Por conseguinte, o mandado de injunção permite o exercício dos direitos e das liberdades constitucionais e prerrogativas inerentes à nacionalidade, à soberania e à cidadania, caso inexista norma regulamentadora. Ao assegurar um direito, o mandado de injunção tem dois pressupostos: um direito constitucional apresentado por alguém e a falta de norma regulamentadora a obstaculizar seu exercício.

Além disso, a Constituição Federal de 1988 institui o "habeas data", no artigo $5^{\circ}$, LXXII:

Art. $5^{\circ}-(.$.

LXXII - conceder-se-á "habeas data": a) para assegurar o conhecimento de informaçoes relativas à pessoa do impetrante, constantes de registros ou bancos de dados de entidades governamentais ou de caráter público; b) para a retificação de dados, quando năo se prefira fazê-lo por processo sigiloso, judicial ou administrativo.

Para a utilização do "habeas data", beneficiado com a gratuidade, é necessário que os dados sejam de caráter pessoal, que estejam na posse de entidades governamentais, tais como órgãos da administração direita e indireta (autarquias, fundaçōes criadas pelo Poder Público, sociedade de economia mista e empresas públicas).

Por outro lado, a Constituição garante o direito à intimidade, previsto no artigo $5^{\circ}$, X:

Art. $5^{\circ}-(.$.

$\mathrm{X}$ - são invioláveis a intimidade, a vida privada, a honra e a imagem das pessoas, assegurado o direito a indenização pelo dano material ou moral decorrente de sua violação.

\section{VII}

Ao contrário do que quase sempre se nota, o Direito Educacional não se reduz a uma simples, às vezes simplória, exposição da legislação do ensino.

O Direito Educacional consiste numa área de estudos jurídicos, com contribuiçôes importantes, como mais recentemente as de Nina Beatriz Ranieri e de Edivaldo M. Boaventura.

A educação, na Constituição Federal de 1988, é um bem jurídico, principalmente porque com ela se constrói uma sociedade livre, justa e solidária e só com ela se garante o desenvolvimento nacional, dentro do que determina o seu artigo $3^{\circ}$, no qual se acham os objetivos fundamentais da República Federativa do Brasil. 
Como direito público subjetivo, a educação pode ser protegida por ser um bem jurídico, individual e coletivo, com a força de direito de ação.

A Lei no 9.394, de 20 de dezembro de 1996, estabelece as diretrizes e bases da educação nacional, conforme ordenado no artigo 22, XXIV, da Constituição, disciplinando a educação escolar, efetivada sobretudo pelo ensino em instituições próprias. Esta Lei tem dado oportunidade à abundância de normas regulamentares, impossibilitando a flexibilização das atividades educacionais.

Então, nem sempre as previsões constitucionais são levadas em conta e não se concretizam, quando na verdade, de um lado, significam direitos individuais e sociais e, de outro, obrigaçôes do Estado.

Deve-se prestar atenção igualmente no fato de a Constituição Federal de 1988 dividir os encargos harmoniosamente entre a União, os Estados e os Municípios, sob a coordenação da União.

As atribuições da União estão claras nos três primeiros parágrafos do seu artigo 211, em que são especificadas as "competências materiais" dos membros da federação, e em outros artigos em que são apontadas suas "competências materiais privativas", como nos casos do artigo 21, IX; do artigo 34,VII, "e"; do artigo 211, parágrafo $1^{\circ}$; do artigo 212, "caput"; do artigo 206, VII; do artigo 209, II. Nas disposições constitucionais, repartem-se competências materiais entre a União, os Estados e os Municípios, conciliando atribuiçōes privativas e atribuições comuns

A Constituição de 1988 não concede atuação prioritária da União a qualquer nível de ensino, o que, em vista disto, autoriza sua atuação supletiva e redistributiva em todos os níveis educacionais. Assim, a União age supletiva e redistributivamente nos vários níveis de ensino, porém suas competências legislativas são indicadas de modo explícito, ficando aos Estados e aos Municípios o restante.

A organização da educação brasileira segue a mesma direção da organização político-administrativa da República, fundamentada no federalismo, havendo descentralização normativa e executiva, de acordo com o artigo 18, "caput" da Constituição: "Art. 18. A organização político-administrativa da República Federativa do Brasil compreende a União, os Estados, o Distrito Federal e os Municípios, todos autônomos, nos termos desta Constituição."

O federalismo constitucional mostra a ausência de hierarquia entre o sistema de ensino da União, o dos Estados, o do Distrito Federal e o dos Municípios, a não ser quando a União legisla nacionalmente sobre 
diretrizes e bases e sobre normas gerais, para ordenar a educação brasileira (cf. Ranieri, 2000).

Ao colocar em prática a Lei $n^{\circ}$ 9.394/96, que fixa as diretrizes e bases da educação nacional, os órgãos do Poder Executivo exercitam o poder regulamentar, uma função administrativa e não legislativa, exorbitando de suas faculdades. O poder regulamentar dos órgão do Poder Executivo, de essência puramente administrativa, ao inverso do que vem acontecendo, não pode exceder-se na regulamentação da Lei no 9.394/96 (Lei de Diretrizes e Bases da Educação Nacional), que altera a organização educacional do Brasil e flexibiliza os processos educativos.

Os abusos do poder regulamentar, na administração educacional, por parte dos órgãos do Poder Executivo, ao produzir normas de comportamento e de organização destinadas a regulamentar a Lei no 9.394/96 (LDB), acabam por conspurcar os preceitos desta Lei e da Constituição de 1988. Tais órgãos administrativos do Poder Executivo, em seu empenho de regulamentar pormenorizadamente a Lei de Diretrizes e Bases da Educação Nacional, complicam e impedem a ação educativa, criando rumos diferentes à descentralização e à flexibilidade, determinados por esta Lei.

Como a Lei no 9.394/96 (Lei de Diretrizes e Bases da Educação Nacional) goza de situação distinta, goza de um regime especial, atuando como lei complementar à Constituição Federal de 1988, não pode ser violada por lei federal ordinária, que venha estabelecer algo diverso do que ela estabelece. Leis complementares, como a Lei da Diretrizes e Bases da Educação Nacional, não podem ser transgredidas em suas "competências materiais privativas", porque as infraçōes a essas leis querem dizer, simultaneamente, infraçōes às normas constitucionais (Constituição de 1988: artigo 22, XXIV, quanto à LDB) (cf. Ranieri, 1999).

\section{VIII}

O regime jurídico da educação, e ainda o Direito Educacional, integram-se no Direito Público e, consequentemente, no Direito Administrativo, pois a educação se põe como direito público subjetivo.

Em se tratando de esfera de investigação e de disciplina normativa, o Direito Educacional se distingue pela natureza pública da educação e pelo predomínio do interesse público sobre o interesse particular, abrangendo não somente as instituiçôes públicas e privadas de ensino, como também os indivíduos vinculados a ele. 
No Direito Educacional, a Constituição Federal de 1988 e, em seguida, a Lei $\mathrm{n}^{\circ}$ 9.394/96 (LDB) mudam essencialmente no campo educacional o regime privado, sujeitando este regime aos princípios constitucionais que guiam a educação brasileira.

Assim, o Direito Educacional, na condição de direito especializado, envolve definiçôes, princípios, comparaçōes com outros sistemas, legislação, jurisprudência, levando em conta as relações jurídicas geradas na atividade educativa e tendo por objetivo proporcionar a educação a todos (cf. Boaventura, 1996; Ranieri, 2000).

No que diz respeito à educação, o direito público subjetivo expressase na faculdade de exigir, proveniente de relação jurídico-administrativa. Pelo direito público subjetivo, o indivíduo tem a possibilidade de exigir da administração pública o cumprimento de prestações educacionais, asseguradas por norma jurídica.

Além disso, pelo poder regulamentar, os órgãos do Poder Executivo possuem a capacidade de editar regulamentos, ou seja, editar regras ou normas, mas tal capacidade não se desliga da lei, não é exercida contra ela, e sim dentro da lei, que a limita e a condiciona. Na administração pública, o regulamento ocupa o mais alto grau na categoria de normas, localizando-se logo abaixo da lei, completando-a. Todavia, configura abuso do poder regulamentar o exercício indevido, por órgãos do Poder Executivo, da competência do Poder Legislativo (cf. Cretella Júnior, 1999, p. 160 e 348).

O Direito Administrativo e, de modo geral, a administração pública estão subordinados a determinados princípios jurídicos, que repercutem no Direito Educacional. São eles, segundo a Constituição de 1988: os princípios jurídicos da legalidade, da impessoalidade, da moralidade, da publicidade e da eficiência (cf. Medauar, 2000, p. 142 e 144).

O Direito Educacional, no entanto, deve partir de idéias como as de Pontes de Miranda, em seus Comentários à Constituição de 1946:

A educação somente pode ser direito de todos se há escolas em número suficiente e se ninguém é excluído delas, portanto se há direito público subjetivo à educação, e o Estado pode e tem de entregar a prestação educacional. Fora daí, é iludir com artigos de Constituição ou de leis. Resolver o problema da educação não é fazer leis, ainda excelentes; é abrir escolas, tendo professores e admitindo os alunos. 


\title{
Politics AND THE BASES OF EDUCATIONAL LAW
}

\begin{abstract}
Taking education as a mediation element, this essay refers to the relationship among society, State and law. It begins defining distinct and remarkable moments of social policy in the XX $X^{\text {th }}$ century, in Brazil: 1) Social policy as a control upon politics (1930-1954); 2) Social policy as control policy (1964-1988); 3) Social policy with no social rights (from 1988 on). The ideas of civil society, citizenship, civil, political and social rights are then reviewed to characterize the so-called democratic Rule of Law and pinpoint some basic elements of democracy. The 1988 Federal Constitution establishes the democratic Rule of Law and clarifies the educational policy to be implemented in Brazil. Based on the numberless articles throughout the constitutional text and on their connection to international treaties, in the field of education, that either precede, are contemporary or follow its promulgation, this educational policy is widely commented. As a matter of fact, the Federal Constitution reinforces the juridical tradition of education in the Brazilian constitutional texts, thus assuming its constitutionality. Actually, through different articles scattered within it, the 1988 Constitution defines the juridical regulation of education, transforming it into a subjective public right. This is a crucial point, since Brazilians have the right to petition the State for education, as the competent authorities cannot be exonerated from their liability. This essay shows that the Educational Law goes beyond a mere exposition of the teaching legislation, inasmuch as education becomes an individual and collective, juridical asset, even though the constitutional determinations are not always enforced.
\end{abstract}

Key words: Social Policies and Citizenship; Society; State and Law; Law and Education; Citizenship and Education.

\section{Referências bibliográficas}

BASTOS, Celso Ribeiro. Curso de direito constitucional. $19^{\mathrm{a}}$ ed. São Paulo: Saraiva, 1998.

BOAVENTURA, Edivaldo M. A Constituição e a educação brasileira. Revista de Informação Legislativa no 127, Brasília: Senado Federal, Separata,jul./set. 1995.

Um ensaio de sistematização do direito educacional. Revista de Informação Legislativa no 131, Brasília: Senado Federal, Separata, jul./set. 1996.

CONSTITUIÇÃO da República Federativa do Brasil: promulgada em 5 de outubro de 1988. $24^{a}$ ed. São Paulo: Saraiva, 2000. 
CRETELLA JÚNIOR, José. Dicionário de direito administrativo. $5^{\text {a }}$ ed. Rio de Janeiro: Forense, 1999.

LAURELL, Asa Cristina. "Avançando em direção ao passado: A política social do neoliberalismo". In: Estado e politicas sociais no neoliberalismo. São Paulo: Cortez, 1995.

MAXIMILIANO, Carlos. Hermenêutica e aplicação do direito. $9^{a}$ ed. Rio de Janeiro: Forense, 1981.

MEDAUAR, Odete. Direito administrativo moderno. $4^{a}$ ed. São Paulo: Revista dos Tribunais, 2000.

PINTO FERREIRA. Curso de direito constitucional. $7^{a}$ ed. São Paulo: Saraiva, 1995.

PONTES DE MIRANDA. Comentários à Constituição de 1946 (T. 4). $2^{a}$ ed. Rio de Janeiro: Borsoi, 1963.

RANIERI, Nina Beatriz. Reflexões sobre as implicações da legislação de ensino na vida acadêmica. Cadernos 3, Brasília: Associação Brasileira de Mantenedoras de Ensino Superior, 1999.

RANIERI, Nina Beatriz. Educação Superior, Direito e Estado. São Paulo: Edusp/Fapesp, 2000.

SERRA, Antonio Truyol y. Los derechos humanos. Madrid: Editorial Tecnos, 1968.

SILVA, José Afonso da. Curso de direito constitucional positivo. $8^{a}$ ed. São Paulo: Malheiros Editores, 1992.

VIEIRA, Evaldo Amaro. Estado e miséria social no Brasil: de Getúlio a Geisel. $4^{a}$ ed. São Paulo: Cortez, 1995. 